University of New Orleans

ScholarWorks@UNO

Winter 2008

\title{
Displacement in French/Displacement of French: The Reggae and R'n'B of Tiken Jah Fakoly and Corneille
}

Olivier Bourderionnet

University of New Orleans, obourde1@uno.edu

Follow this and additional works at: https://scholarworks.uno.edu/fl_facpubs

Part of the French and Francophone Language and Literature Commons

\section{Recommended Citation}

Bourderionnet, Oliver. "Displacement in French/Displacement of French: The Reggae and R'n'B of Tiken Jah Fakoly and Corneille." Research in African Literatures 39.4 (Winter 2008): 14-23.

This Article is brought to you for free and open access by the Department of English and Foreign Languages at ScholarWorks@UNO. It has been accepted for inclusion in Foreign Languages Faculty Publications by an authorized administrator of ScholarWorks@UNO. For more information, please contact scholarworks@uno.edu. 


\section{Displacement in French / Displacement of French: The Reggae and $R^{\prime} n^{\prime} B$ of Tiken Jah Fakoly and Corneille}

Popular music has this advantage over literature: its message is easily accessible to a wide audience and through a variety of media that go from radio to peer to peer networks. Thus, taking a look at popular music artists, for whom it has been established that they are having an impact both in Africa and in Europe, has its appeal. While a large portion of African literature finds most of its public in the West, popular music, on the other hand, travels more freely across continents. This paper examines the works and situations of two francophone singer-songwriters from Africa, Tiken Jah Fakoly and Corneille, and their relationship to France, a country in which they do not live, but where their careers in the global music industry are now rooted. Tiken Jah Fakoly (born Doumbia Moussa in 1968) is from the Ivory Coast and is living in exile in Bamako, Mali. Corneille (born Corneille Nyungura in 1977) is from Rwanda, lives in Montreal, and recently became a Canadian citizen. Both artists are signed to French record labels.

In discussing these musicians' productions and receptions through the notion of displacement we will attempt to answer important questions regarding language, identity and the social role of the African pop artist in France and the Francophone world. Tiken Jah Fakoly and Corneille embody the mediation 
between publics from two continents and the global music industry within a particular geo-political context. They belong to a group of artists whose productions signal a shift in French popular music representations of Africa and Africans. Discussing these artists' choice to sing in French will allow us to reflect on the position of the French language in the English-dominated world of popular music. In different ways, Corneille and Tiken Jah Fakoly are expanding the span of the French language in the pop music world. This displacement of Erench will also have to be analyzed in the light of strategic diversification efforts made by the French music industry and indirect forms of support the latter receives from the French government.

It will be useful to begin with a short background presentation of both artists in order to give the reader a measure of their popularity and relevance in the context of this study. Corneille's two albums Parce Qu'on Vient de Loin (2002), and Les Marchands de Rêves (2005) were released by Wagram Music, an independent French label, while Tiken Jah's last two albums Françafrique (2002) and coup de Gueule (2004) came out on Barclay / Universal, a French division of the "major" Universal. Tiken Jah has also released several albums in the Ivory Coast, among them Cours d'Histoire (1999), which later became available in Europe.

Since the year 2004, Tiken Jah and Corneille have enjoyed large followings. The profession and the media have granted them high visibility through television appearances, festivals, 
benefit concerts and numerous awards. Corneille's album sales in France for the year 2004 reached the top ten list and sold in the rest of Europe as well, earning him a 2005 “Border Breaking Award," a new award, part of the "European Music Policy" project. The award is given to new artists with albums that are successful outside of their country of origin within the European community. Although he toured in Japan last year, Corneille performs mostly in the "Espace Francophone." Outside of Europe he has appeared in Quebec, the French Caribbean, and he took part in the Africa Live 2005 "Roll Back Malaria" concert in Senegal, along with Yousou N'dour, Angelique Kidjo, Salif Keita, Tiken Jah Fakoly, and others. Corneille was also chosen by representatives of national TV channel France 3 to compose the song that represented France at the Eurovision contest in May of 2006.

Although he is currently the best selling African reggae artist in France, Tiken Jah Fakoly's albums have never reached the top ten list of yearly sales there. Coup de Gueule (2004) entered the top 200 list of best selling new albums in France at number 19 and remained charted until the end of 2005. Francafrique (released in 2002), which won best album in the "reggae/ragga/world" category of the Victoires de la musique (an equivalent of the Grammy Awards in France), was recently ranked in the top 30 best selling back-catalogue albums. Tiken Jah's sales in Africa, although much more difficult to measure due to different methods of distribution and duplication there, are estimated at over 500000 for Mangercratie (released in 1999), 
which earned him superstar status in the entire West African region. Contrary to Corneille, whose songs are sung exclusively in French, Tiken Jah's music features his singing in Dioula and occasionally in English. This linguistic diversity as well as his "World Music" affiliation seem to have facilitated various appearances in New York city and the UK. Tiken Jah can be heard on the radio and seen performing in non-French speaking European countries (Holland, England, Germany, Hungary, Portugal, Sweden) but his largest following comes mainly from the Espace Francophone and particularly from West-Africa.

\section{Où Veux-tu Que $J^{\prime}$ aille?}

In this first section we will focus on a few songs by Tiken Jah Fakoly and Corneille that deal with exile and immigration. For both Tiken Jah and Corneille, the notion of displacement starts at the political level and blends with personal experience. The Ivory Coast reggae star, Tiken Jah, has been famous for voicing strong political opinions in his songs since the tormented election period that followed the death of President HouphouëtBoigny in 1994. In 2002, after rebel forces seized power in the north of the country, Tiken Jah fled to Bamako, Mali, for what he called "personal security" reasons. He has not been able to return home since. In "Où veux-tu que j'aille" (2004), a song cowritten with former Zebda leader / political activist Magyd Cherfi, and featuring Mouss et Hakim Amokrane (former Zebda members as well) parallels are drawn between victims of ethnic and political discrimination in the Ivory coast and the situation 
of minorities in France. In the first verse Tiken sings: "Tu as brûlé ma maison d'Abidjan / Parce que je ne suis pas de ton clan / ... / moi je suis né là / Pourquoi veux-tu que je m'en aille?" and in the second verse the Amokrane brothers sing in turn : “V'là qu'chuis tombé côté face de la pièce / Pile dans le délit qu'on appelle de faciès," echoing the woes of the population of North and West-African descent, who suffer racial profiling on a daily basis through identification controls by French police or when searching for employment. ${ }^{i}$ In the third verse Tiken's lines make a direct reference to the unfair treatment of African soldiers who fought for France in the two world wars and whose contribution is often forgotten: "Nous sommes tous nés là / Exilés sans autre choix / Nos grands-pères se sont sacrifiés / Nos papas se sont intégrés / Même si on nous traite d'étrangers / Pourquoi veux-tu qu'on s'en aille." ${ }^{i i}$ This verse also raises the issues of racism and ethnic tensions in France and the Ivory Coast, both of which experienced a considerable influx of immigrants since the 1960s. Both countries are struggling with problems of racism toward their citizens born to parents of recent Muslim immigration.

Although Corneille was born in Germany, he grew up in Rwanda. ${ }^{i i}$ In 1994 he survived a massacre that claimed the lives of all his family members. He relocated to quebec in $1997 \mathrm{via}$ Zärre, now the Democratic Republic of Congo, and Europe. The lyrics of his first solo album Parce Qu'On Vient de Loin, dedicated to the victims of the 1994 genocide tell of the tragedy 
he lived through and express a strong determination to overcome his grief. His song "Terre" tells of his displacement from Rwanda to Quebec where he is "chez [lui] malgré l'apparence," (at home, although I don't look like I belong) and where he has found "un nouveau sens à la patrie" (a new meaning to homeland). The message of this song is one of an untroubled immigration, which strongly contrasts with that of "Où veux-tu que j'aille." "Terre" seems to celebrate a successful North-American multi-cultural system in which Corneille feels welcome: "je peux rêver, je peux tout faire, je suis bien ici." (I can dream / I can do anything I want / I feel good here). The temptation is strong to contrast this type of discourse with the situation of the young people in the French banlieues who accounted for a large part of Corneille's following in his rise to success in 2003 and 2004 . As Stuart Hall expresses in Reflections Upon the Encoding / Decoding Model, both the artist and the audience are involved in a process of articulating cultural meaning (261). In that process of articulation, elements that do not necessarily belong together become connected. We can speculate that to the ears of youth from the "banlieues," Corneille's lines "je peux tout faire / je peux rêver / je suis bien ici" might resonate with a longing for an imaginary "elsewhere." One can also wonder about the meaning of a recent survey conducted by the polling company Ifop for Le Journal du Dimanche, which placed Yannick Noah and Zinédine Zidane in first and second place of "les personnalités préférées des français." Corneille ranked $18^{\text {th }}$ as a new entry for 2005 . All 
the other celebrities being French citizens (Djamel Debbouze is in the $11^{\text {th }}$ position) we can only imagine that Corneille must now be considered French in France. This rallying behind Noah and Zidane, who now occupy places long held by le Commandant Cousteau and L'Abbé Pierre, seems to speak more about who the French like to see on television today than about their feelings towards a multicultural society. In putting forward the success stories of French stars of immigrant descent, who are notorious for not taking strong stances against discrimination, the survey eventually echoes the current government's push towards "une immigration choisie."

The variability in articulation of cultural meaning that we remarked on in the case of Corneille's song "Terre," can be further illustrated by Tiken Jah Fakoly's song "Le Balayeur" which in the Ivory coast will be understood as a direct reference to General Guéi's short-lived experience as the leader of the country in 1999. In France, for those listeners who are not aware of General Guéi's promises to "balayer la maison" (to sweep up the place) the song's chorus line "Le balayeur balayé (the sweeper swept away) can very well be understood as a reference to unskilled workers and the disillusionment of African immigrants who end up with the jobs that nobody else wants. In "Question de peau" a duo with Bernard Lavilliers which appeared on the latter's 2004 release Carnet de Bord on Barclay / Universal, Tiken Jah Fakoly and Lavilliers sing of the experience of illegal immigrants hiding from customs officers to cross borders, and of 
being arrested for a "question de peau, de veine et de couleur" (question of skin, of luck and color). iv

Undocumented workers also appear in Corneille's title song for his new album Les Marchands de Rêves in which he addresses a divine figure asking him/her to come down and send a message of hope: "dis-leur qu'ils ont droit au bonheur / et qu'un jour ce sera eux les meilleurs / pour qu'ils restent dignes / dis-leur que demain est à eux / qu'ils fassent à la misère leurs adieux / en dépit des signes. ${ }^{\vee}$ The song sends a message of faith and of hope for a better day that seems just around the corner to a displaced community all over the world: "Dis-leur qu'on arrive / Dis-leur que tant d'autres nous suivent / Dis-leur qu'on est plus qu'à quelques pas / Dis-leur qu'on est par milliers / Avec ou sans papiers / Des marchands de rêves." ${ }^{\mathrm{vi}}$ Both the architecture of the song, which culminates in a fervent chorus reminiscent of "We Are the World," and the images of the video clip, which displays Christian crosses and people praying, support the religious aspect of the text and show immigrants, most of them African, living away from home. With this in mind I would like to turn to the second section of this paper to focus on Corneille and Tiken Jah Fakoly's works as examples of the French music industry's shifting interest towards cultural representations that propose different models of French identity or depart from France as the center. 


\section{Black-Atlantic and pan-African representations}

The video clip which accompanies the single "Les Marchands de Rêves," the title song of the second album which Corneille had warned would be turned more towards Africa than his previous one, is filled with images of Africans of all ages living in the cold climate of a North-American city. A strong emphasis is placed on showing families, children, people at work, people separated from loved ones, people living in temporary housing conditions, or people in transit. In 2003, the title track of the album Parce Qu'On Vient de Loin was also released in a video clip format and both clips develop the theme of displacement present in the songs' lyrics. In "Parce qu'on vient de loin" Corneille can be seen singing to the camera while his surroundings alternate between an urban environment, full of concrete, and a peaceful forest. Neither in "Les Marchands de Rêves" nor in "Parce Qu'On Vient de Loin" is there a direct reference to Africa, but the "nous" and the "on" which we also find in "Notre Jour Viendra" seem to be saying "us Africans." In both songs, references are made to "nos mères," "nos pères," to hard times, and to suffering from the cold winter. The chorus in "Parce Qu'On Vient de Loin" refers to a group sharing a common ancestry in a faraway place, a group that has seen so many disasters that it has learned to live each day as if it were the last (the same idea is developed in "Notre Jour Viendra"). It also addresses another group, those who do not know, whose experience has not granted them that wisdom: "Alors on vit chaque jour comme le dernier / Et vous feriez 
pareil si seulement vous saviez / Combien de fois la fin du monde nous a frolés / Alors on vit chaque jour comme le dernier / Parce qu'on vient de loin." ${ }^{\text {ii }}$ Both songs and video clips therefore establish a connection between the displaced people of a group. They reflect the non-essentialist vision of a diasporic African identity based on a common origin, which Paul Gilroy defines in The Black Atlantic: Modernity and Double-Consciousness. As a French-produced African artist who claims mostly African-American musical influences, Corneille's work signals the emergence of a Black-Atlantic awareness in French language popular music similar to the one Gilroy observes in Britain's pop scene.

Tiken Jah Fakoly was recently described in the Washington Post as "a thorn in the side of African politicians." The majority of his songs address political corruption, neocolonialism, tribalism, violence and injustice. From the beginning, his recordings have carried a message of unity for Africa and a yearning for change. His 2002 release Françafrique featured his most successful song so far, "Le pays va mal," in which he deplores the divisions at work in his own country. Tiken Jah claims Africa as the focal point of his political involvement as an artist. A strong advocate of the "Drop the African Debt" campaign, he participated in the anti-G8 demonstrations in Geneva in 2003. His latest release coup de Gueule features a song titled "L'Afrique doit du fric" echoing the 1980's "Afrique Sans Fric," a song by another famous Francophone artist from Cameroon: Manu Di Bango. Tiken describes himself as an educator, an artist whose 
role is to relay information to the people and in turn to make their voices heard by "les politiciens." Apart from "Où veux-tu que j'aille" and "Question de peau" the two songs we discussed earlier and which he performs with France-based artists, Tiken Jah Fakoly's lyrics do not reveal strong ties with France other than linguistic ones. The video clip for "Le Pays Va Mal" does open with the image of an African man selling souvenirs at the bottom of the Eiffel Tower but soon the images shift to a WestAfrican city. On the other hand, his sharp discourse on the situation in the Ivory Coast and in Africa in general is instrumental in promoting awareness of African issues in France as well as in raising questions about Africa's colonial legacy at a time when some French politicians would have a law in favor of teaching the positive aspects of colonization. Also, the song "Françafrique" points an accusing finger at France's politics in Africa: "La politique France Africa c'est du blaguer tuer / ... / Ils nous vendent des armes / Pendant que nous nous battons / Ils pillent nos richesses / Et se disent être surpris de voir l'Afrique toujours en guerre." ${ }^{\text {viii }}$ Tiken Jah is hardly the first French language African artist to be signed to a French label, but his focused political discourse and involvement with activist groups in Europe (such as the Associations Survie and Attac) single him out as a strong dissenting voice heard in French, both in Europe and in Africa. ${ }^{\text {ix }}$ According to a statement made last year at the Festival International de Grand Reportage d'Actualité (FIGRA), reporter Sylvain Taillet, who is also Tiken Jah's 
executive producer and artistic director, the African reggae musician was the victim of radio censorship in France, resulting from pressuring by the Quai d'Orsay, the French Foreign Ministry. The African news agency PANAPRESS relayed that information in the following paragraph:

“La vente des cassettes de Tiken Jah a été censuré à Abidjan pendant une certaine période sous la pression des Jeunes patriotes, mais ici en France également, le Quai d'Orsay a intimé à certaines radios publiques de ne pas passer le titre "Quitte le pouvoir,'" a affirmé Taillet, qui a réalisé avec un autre journaliste français, Eric Mulet, le documentaire "Tiken Jah Fakoly: Mon pays va mal." Parmi ces radios, Sylvain Taillet a cité Radio France internationale (RFI) et France Inter, qui ont été obligées de "mettre un bémol" dans la diffusion de certaines chansons de Tiken Jah après le bombardement d'un campement de l'opération Licorne par l'aviation militaire ivoirienne, entraînant la mort de neuf soldat français. Interrogé par la PANA, l'artiste ivoirien a confirmé l'information et indiqué qu'en plus de 'Quitte le pouvoir,' une autre de ses chansons, 'Mal élu,' a également été censurée. ${ }^{x}$

In that light, the fact that Radio France Internationale, the largest airwave promoter of African musicians in the Francophone world is almost entirely funded by the French Foreign Ministry further illustrates France's ambiguous position toward 
its former colonies.

\section{French displaced}

We have seen how Tiken Jah and Corneille's productions represent a shift in French language popular music representations of Africanness. While signed to Paris-based record companies they emphasize a transnational belonging and transform the way their audiences in France and elsewhere articulate meaning around an African identity .

Let us now turn to the final section of our discussion, which regards language. First, we should take a minute to consider the musical idioms in which both artists express themselves. The musical categories with which they are affiliated are Soul or R'n'B for Corneille and African Reggae for Tiken Jah. Soul and reggae, as we know, emerged on the American side of the Atlantic. Displacing French in order to bring it into a musical territory dominated by English is part of the appeal Corneille and Tiken Jah Fakoly see in their artistic endeavor. They claim a strong attachment to the French language, which they view as a distinguishing quality of their work and as a challenge in the music business. In 2005, interviewed by Anne-Laure Barral for radiofrance.fr, Tiken Jah explained that given the high number of different ethnicities in the Ivory Coast, French is the language that makes it possible for his message to be heard by all. In fact, it was at the time when he started singing in French that he became popular all over West Africa. Answering another question concerning his rapport to the French language he praises 
the "circuits des Alliances Françaises" and the Centres Culturels Français for their promotion of African Artists such as Rokia Traoré and himself. He remarks that through this French network he was able to tour in all the countries of Central Africa in June 2004 and he concludes with this very interesting statement: "La Francophonie est une porte de sortie assez importante pour beaucoup d'artistes africains." ${ }^{\mathrm{xi}}$ It must be noted however, that the African artists who sing in their ethnic language tend to reach a wider audience on the "World Music" scene, mostly due to the perennial question of perceived authenticity. As Gilroy put it: "Authenticity enhances the appeal of selected cultural commodities and has become an important element in the mechanism of the mode of racialization necessary to making non-European and non-American musics acceptable items in an expanded pop market" (99). Interviewed about Tiken Jah, whom he considers "cutting edge" Christian Mousset, director of the Festival des Musique Métisses in Angoulème remarks that to some festival organizers, African artists singing in their ethnic language still appear more authentic. And it should not come as a surprise that the French-signed African artists, which the French record industry has had the most success exporting to the United States (Khaled, Souad Massi, Rokia Traoré), are artists who sing in one of their countries' indigenous languages. The recent success of Amadou \& Mariam Dimanche A Bamako, featuring Tiken Jah Fakoly on "Politic Amagni," seems to be the exception that confirms the rule, although most of the songs on the album feature a blend of French 
and Bambara. This album has become the most successful African recording in Europe and America in history. In recent years the French industry's "World Music" category has become the second best exporter behind the very lucrative "Techno" category. Through the "Découvertes RFI- Musiques du Monde," an annual contest open to African and Caribbean artists, Radio France Internationale acts as a discoverer of new talents. Winners earn a cash prize from the French Foreign Ministry; they are featured in promotional concerts in Africa and in Paris (organized by the Organisation Internationale de la Francophonie) and they are later taken under the wing of a French music label. Tiken Jah Fakoly who won the RFI découverte award in 2000, Rokia Traoré (1997 laureate), and Amadou et Mariam (1995 laureates) are living examples of French cultural policy working hand in hand with the French music industry (if we disregard instances such as the one we mentioned earlier concerning pressures to limit airplay of certain songs judged too inflammatory).

In the case of Corneille the use of the French language presents a different challenge. At the time when he released Parce Qu'On Vient de Loin in France, the type of Contemporary $R^{\prime} n^{\prime} B$ sound (reminiscent of Boyz II Men) that characterizes that album had no equivalent in French pop. Traditionally, all styles coming from America and Britain eventually find their way into the French language pop market. The style of vocal performance that Corneille embraces, as is the case with Jazz, Rap, and Hiphop, requires particular attention to rhythm, sound and 
accentuation, when writing and performing the lyrics. Charles Trénet had already experimented with that in the 1930's when singing "Y a d'la joie" by putting the stress in an unusual place in the sentence ( $Y$ a D'LA joie). Displacing the stress pattern makes it possible for the singer to adhere to the exigencies of a jazzy phrasing. Corneille's accentuation and speech at times give the effect of an English sentence using French words. A line such as "On dit souvent, mais c'est sans savoir" becomes: On DIT souVENT mais C'EST, Sans saVOIR. The marrying of the French language to a style of music in which rhythm is the main vehicle imposes changes that affect the language in its very structure. "J'ai vite compris qu'il y avait une façon différente d'approcher les mélodies, de créer différemment en fonction de la langue." ${ }^{\text {xi }}$ Corneille declared in an interview with RFI's Pierre-René Worms. The displacement thus appears dual. It concerns not only the adaptation of the French language stress pattern to one that ressembles English, but also the musical approach which is, in turn, influenced by the language's idiosyncracies. With Corneille, the French language and la "chanson française" (of which he is now considered a "flagship") takes a different step towards "franglais." The singer uses very few English words in his songs, but his lines are often punctuated with "yea-ah" and "we-ell" as they are in American soul music. English verb constructions find their way into the French syntax: "Si on a quitté c'est pour revenir gagnant," (the verb "quitter" is used without an object -in the sense of "partir" as it is 
possible to do in English with the verb "to leave"). "Ça me fait penser" is used in the sense of "ça me fait réfléchir"(It makes me think).

The complex question of the language, "chosen" or "imposed," that surrounds literature written by authors, whose origins lie in former European colonies, is one that academics are familiar with. In the case of Corneille and Tiken Jah, and to some extent, for a large portion of French singing singer-songwriters today, the language question doesn't involve a conflict between French and an African language or French and a regional language, but a conflict with English, which requires constant negotiation. Tiken Jah confesses he is studying English because his singing in this language is not sufficiently self-assured, while Corneille is currently working on recording an Album in English to be released in september of 2006 .

Corneille and Tiken Jah are no strangers to the appeals of the large English language market. Most French-singing artists who meet success in the "Espace francophone" usually make an attempt at widening their audience in Britain and North America by launching an English language record. For the most part, these efforts go largely unnoticed. This is what Corneille declared in an interview a few years ago, before the project of the English album came about:

C'était plus intéressant d'appartenir à un courant précurseur. Je n'avais pas d'autre choix que de créer un truc. En R\&B, soul, il n’y avait pas vraiment de référence, 
il a fallu que je crée, que je me trouve un style. J'ai du inventer un truc, chanter en français sans que cela fasse mal aux oreilles! Le fait est que je suis francophone et les Etats-Unis restent un marché super fermé. Si on ne vient pas de là, il ne faut pas se faire d'illusions. Dans l'histoire de la musique américaine, personne n'a vraiment réussi à faire de musique là-bas. Il y a une fermeture d'esprit. Le hip hop leur appartient, alors ils le protègent et ça ferme les portes aux artistes. Je n'ai pas envie d'aller à la conquête des Etats-Unis. Si ça arrive c'est que la demande sera là, sinon, c'est l'Europe qui m'intéresse le plus. On peut se permettre plus de choses que sur la scène américaine. Quand je me remettrai à l'anglais, j'aurai des choses à apporter à la scène anglo-saxonne. Mais j'ai appris énormément en français, et j'écris plus de choses que si je m'étais tenu à l'anglais. ${ }^{\text {xii }}$

Corneille's position appears rather uncomfortable in this statement; singing in French does not sound as a first hand artistic choice, but rather as a lucky compromise. As has been the case for many musicians in France and Canada who began a career singing in English, French offered Corneille a way out, allowing for a much more successful career. For many pop musicians in the world, the appeal of English stems from having been exposed to English language recordings in their formative years. Singing in the language used by your main musical 
influences gives your own work an added layer of authenticity. Although Tiken Jah has not released any songs in English in recent years ("Soldier" was apparently recorded but not mixed in time for coup de Gueule) he did yield to the appeal of authenticity by tracking parts of his last two albums at Tuff Gong Studio in Jamaica, with former Bob Marley musicians.

Corneille and Tiken Jah Fakoly are examples (and there are numerous others) of diversifying efforts deployed by the French music industry to compete with the ubiquity of English language products. In the case of Tiken Jah, we could open a debate on cooptation and ask to what extent his situation as a Frenchdiscovered African talent does reflect in turn the very exploitation of African goods by the West, including cultural ones, that he so vehemently denounces. We could also question the effectiveness of French cultural initiatives and state funding that promote new African artists who later become signed to American-owned global record companies such as Universal (which controls roughly a quarter of all album sales in the world). In approaching Corneille and Tiken Jah's productions from different perspectives we were able to raise questions regarding identity and language as they come into play within the world of current popular music in France. In doing so we have highlighted different dynamics of displacement involving the use of the French language in the global context and the increasing role of the African artist as promoter of transnational and intercultural exchange. 


\section{Notes}

i "You burnt down my house in Abidjan / because we don't belong to the same clan /. . / I was born here / Why do you want me to leave / . . / they tossed a coin / but some heads just can't win / Guess I was born with the wrong face on me" (my translation).

ii We were all born here / Exiled with no other choice / Our grand-fathers made sacrifices / Our fathers became integrated / Even if people calls us foreigners / Why do you want us to leave" (my translation) .

ii Born to parents who were fond of French culture, Corneille was named after the $17^{\text {th }}$ century French playwright. iv For obvious marketing reasons Barclay / Universal released Lavilliers's album which features the duet with Tiken Jah Fakoly just a week before coup de Gueule.

v "Tell them they have a right to happiness / that one day they will be the winners / so they'll keep their dignity / tell them tomorrow belongs to them / they will say good-bye to misery / despite they way things are looking now" (my translation). vi "Tell them we're on our way / Tell them so many are following / Tell them we're just a few steps away / Tell them that we come by the thousands / whether legal or not / Traders of dreams" (my translation) 
vii "So we live every day as if it were the last / And you'd do the same if you only knew / How may times we came this close to our world collapsing / So we live every day as if it were the last / because we've come from far away" (my translation). viii "French-African politics is joke and kill/They sell weapons to us / While we fight / They steal our richess / And pretend to be surprised that Africa is always at war"

ix The term "Françafrique" was first used by the economist François-Xavier Verschave as the title to one of his books. Verschave also founded the N.G.O. Survie. * The sale of audio tapes was censored in Abidjan for some time, under pressure from the Young Patriots, but here in France as well, the Quai d'Orsay ordered a few public radio stations to not play the song "Quitte le pouvoir" ("Leave Power"), said Taillet who, with Eric Mulet, another French journalist, co-directed the documentary "Tiken Jah Fakoly: Mon pays va mal" ("My country is sick"). Sylvain Taillet named RFI and France Inter among the radio stations who were asked to "lower the volume" ("mettre un bémol") in broadcasting some of Tiken Jah's songs following the bombing of a Unicorn Operation camp by the Ivorian Air force during which nine French soldiers were killed. Interviewed by PANA, the Ivorian artist confirmed the statement and indicated that besides "Quitte le pouvoir" another one of his songs "Mal élu" ("Poorly Elected") had also been censored. (my translation) 
xi "Francophonie is a major way out for many African artists." (my translation)

xii "I soon figured out that there was a different way of approaching melody writing, that the creative process varies according to the language." (my translation)

xiii It was more interesting to belong to an innovative trend. I didn't have any other choice than to create my own thing. There weren't really any references in R\&B and soul music. I had to create it, find my style. I had to come up with something, sing in French without hurting anyone's ears! The fact is that I am a speaker of French, and the United States remains an extremely closed market. If you are not from there, you are in for a reality check. In the history of American music, no one has really managed to go over there and play. There is a lack of open-mindedness there. Hip-Hop belongs to them so they are protecting it and closing doors on artists. I do not feel like trying to conquer the US. If it happens it will be because there is a demand there, otherwise, I am more interested in Europe. You can try more things here than on the US scene. When I go back to singing in English I will have things to bring to the Anglo-Saxon scene. But I have learned a lot with French and I write more things than I would have if I had stuck to English (my translation) 


\section{Works cited}

Barral, Anne-Laure. Chanson: Reflets de la Création Francophone. Portrait de Tiken Jah Fakoly. Radio France <http://web1.radiofrance.fr/reportage/dossier/index.php?rid= $105000029 \& \mathrm{aid}=105000034 \&$ formtype=dossier \&arch=1>

Classement Officiel des Meilleurs Ventes de Disques en France. <http://www.ifop.com/europe/sondages/topback/bck0527.stm>

Corneille."Terre" Parce Qu'On Vient De Loin

Wagram $3087782,2002$.

Gilroy, Paul. The Black Atlantic: Modernity and Double

Consciousness. Cambridge: Harvard UP, 1992.

Hall, Stewart. "Reflections Upon the Encoding/Decoding Model." In Jon Cruz and Justin Lewis (eds.), Viewing, Reading, Listening: Audiences and Critical Reception. Boulder: Westview, 1994, pp.253-274.

Lavilliers, Bernard; Tiken Jah Fakoly."Question de Peau" Carnets de Bord Barclay / Universal EU 9823276, 2004.

Le Journal du Dimanche. <http://www.lejournaldudimanche.fr/sondages / detail_top50.php>

"Le pays va mal" Music Video, dir, Xavier De Nauw, Barclay / Universal, 2002.

"Les marchands de rêves" Music Video, dir. Ivan Grbovic, Nùfilms, 2006.

PANAPRESS, African News Agency <http://www.panapress.com/

archive. asp?code=fre\&dte=21/03/2005>

"Parce qu'on vient de loin" Music Video, dir. Maxime Giroux, NùFilms, 2003.

Skelton, Rose. "Ivorian Reggae Star Fakoly Strikes Dissenting Chord" The Washington Post, March $21^{\text {st }}, 2006$.

Tiken Jah Fakoly."Le Balayeur" Françafrique Barclay / Universal EU 5896132, 2002.

Tiken Jah Fakoly. "Quitte le pouvoir" Coups de Gueule 
Barclay / Universal EU 9823320, 2004

Various Artists. 'We Are the World' Polygram 824 822, 1985. 